\title{
Mapping the role of 'transnational family habitus' in the lives of young people and children
}

In this article we develop the concept of 'transnational family habitus' as a theoretical tool for making sense of the ways in which children and young people of migrant background are 'doing families' transnationally. Drawing on over a decade long cumulative research on Caribbean and Italian families in the UK, as well as on a new joint research project, the article firstly investigates the opportunities and consequences of a transnational family habitus on family arrangements, kinship relationships and identity within a transnational context. Secondly, it analyses the role of these young people's structural location in Britain in shaping the boundaries of their transnational family habitus. We argue that a transnational family habitus should be seen as asset, which can potentially disrupt conventional understandings of belonging and processes of inclusion and exclusion. However, we also detail how social divisions of class, race, and increasingly migration status, shape such habitus.

Key words: transnational family habitus, transnational children and young people, Caribbean and Italian families, identities, social divisions, inclusions/exclusions

\section{Introduction}

In recent years there has been a plethora of studies emerging out of the UK addressing the transnational experience of families (Bauer 2006, Charsley 2006, Christou 2010, Goulbourne at al 2010, Ryan et al 2009; authors' own publications anonymised for review). In this article, we develop the concept of 'transnational family habitus' as a theoretical tool for making sense of the ways in which children and young people of migrant background are 'doing families' (Morgan 1996) transnationally. Influenced by Bourdieu's notion of 'habitus' (1986), we define 'transnational family habitus' as a structured set of values, ways of thinking and 'being' within the family that is built up over time through family socialization, practices and cultural traditions that transcend national boundaries. It is our intention 
to contribute a more nuanced understanding of transnational family life experienced by these children and young people than is currently present in the literature. We illuminate understanding by firstly investigating the opportunities and consequences of a transnational family habitus on family arrangements, kinship relationships and identity within a transnational context. Secondly, by analysing the extent to which such transnational family habitus is shaped by young people and children's structural location in Britain.

\section{Research background}

Our analysis is developed from the vantage point of over a decade long cumulative research on Caribbean and Italian families in the UK. The origins of the research stemmed from our work within the Families and Social Capital Research Group at London South Bank University in the UK that began in 2003. The group's work focused on the dynamics of family change and processes of social capital paying particular attention to identities and values, trust and reciprocity and caring for and about. Our broad perspective on understanding transnational families led us to examine the lived experiences of family members that are scattered across national boundaries and the issues this raised about such matters as migration, identities, communities, resources and relationships in the contemporary world. The Caribbean project investigated processes of identity formation among Caribbean diasporic youth looking at how these young people utilise social capital resources within their family relationships and community networks as social resources. The material was collected through 30 in-depth interviews with young people of Caribbean origin and 50 kinship/family members in the UK and the Caribbean across all age groups (anonymised for review).

The Italian project explored various aspects of family life and social capital. These included the functioning of mutual and reciprocal relations related to care, the role of rituals and the formation of transnational identities. The material was collected through participant observation and 50 in depth qualitative interviews in a number of sites both in the UK and in Italy. Italians from the three main migration stages to the UK (pre-war, post-war and recent student and professional migrants) were 
interviewed including both first generation migrants and their offspring (anonymised for review). A non-purposive method of sampling (snowballing) was used to select a diverse sample across contrasting urban locations in the UK where there was a high density of Caribbean and Italian settlements, as well as specific territories across the Caribbean (Jamaica, Barbados, Guyana and St.Kitts) and in Italy (Sicily and Trentino).

Despite marked racial and ethnic differences between Caribbeans and Italians, a key finding of both studies was the significance of transnational and cross-cultural family networks, rituals and celebrations in shaping ethnic identity. This earlier work has since developed into new and collaborative studies that extended out and broaden the scope of our studies to focus on Italian children living in transnational families (anonymised forthcoming). In 2015, multiple narrative interviews and arts-based activities were conducted with 12 children aged eight to 17 of Italian origin living in the East Midlands region of Britain. This study focused on the children's transnational experiences and notion of identity and belonging at a time of EU crisis and increased anti- EU migrant sentiments in the UK. A related project 'Youth Matters' investigated how a transnational identity manifests itself in an embodied and physical way with a group of young adults from diverse racialized and ethnic minority communities (e.g. Pakistan, Angola, Ghana, Norway and Ireland). During January to April 2016, weekly three hours workshop sessions took place with a group of 12 young adults (aged between 19- 25 years old). These sessions comprised of group interviews, reflections and also involved the young adults working with a consultant dramatherapist (Erene Kaptani) in undertaking a series of physical exercises and movements which draw from forum theatre techniques (Kaptani and Yuval-Davis 2008). The director and activist Augusto Boal (1979) developed forum theatre, as part of the Theatre of the Oppressed. The framework and set of techniques is based on the principles of collective empowerment and emancipation. In this particular study, the use of forum theatre techniques was utilised as a social intervention tool in order tohelp the young adults to stimulate their creativity and thinking around the way in which their transnational family relationships shapes issues of trust, identity and belonging. This latter study is part of a broader body of research projects funded by the AHRC (Erel and Reynolds 2013-14) and ESRC (Erel, Reynolds and O'Neill 
2016-18)ii focusing on the potential of participatory research methods - specifically forum theatre - to investigate the identity and experiences of individuals belonging to minority ethnic, migrant and transnational communities.. It is not the intention of nor it is within the scope of this paper to discuss the on-going analysis of this project in detail. Nonetheless, later on in the article, we do draw on some of the preliminary data to elucidate our analysis of the importance of transnational family habitus in overcome experiences of social exclusion encountered by young Black adults males in particular.

Examining migrants youth experiences and practices through the framework of 'transnational family habitus' encourages a re-reading of our original and later studies on transnational families, to ask the question, to what extent does the resources, values and practices circulating within transnational families either create or exist as a by-product of 'transnational family habitus'? Reframing our analysis within the present, presents certain methodological challenges. Perspectives on reanalysing and re-visiting data of one's own, and others', over time, with new theoretical insights and awareness and with an altered 'cultural habitus' (Bornat 2005) have been much debated and contested, particularly within the field of qualitative longitudinal studies (Bornat 2006, Henderson et al. 2006, Mauthner et al. 1998, Thomson and Holland 2003). This literature has been especially insightful for us in terms of reflecting on the journey and process involved in the re-contextualising and re-interpreting data for a different purpose than the one it was originally collected for. A key strength in re-visiting data with a different methodological lens is that we are able to observe and document how much of the young adults experiences of 'doing families' is embodied, sensory, physical and visceral. This factor was generally overlooked in our original analysis and reading of the data. However a key limitation with this approach is that we lose sight and diminish the importance of the meaningful interaction which took place between us as the researchers and the participants during our original phase of data collection and analysis. The original interviews which took place in multiple locations across the UK, Caribbean and Italy happened at a particular moment in time when studies of transnational families was a new and emerging academic area of study in the disciplines of migration studies and family studies. As a result our original study is a reflection of this particular 
historical juncture. In re-visiting the data in a new perod of time and with different methodological lens there is the danger that we lose sight of meaningfulness of our original data. To offset some of the challenges in revising data we have deliberately chosen to introduce new and emerging research, alongside our original studies.

\section{Transnational Relationships and Practices of Children and Young People}

Contemporary migrants are embedded in transnational social fields (Levitt and Glick Shiller 2004) that span different countries. Such transnational fields of relations form a significant context for the everyday life of a growing number of children and young people in Europe and beyond (Haikkola 2011, Mand 2010, Moskal 2014, and Fox 2015). Despite the fact there is a growing body of research highlighting transnational relations and practices of children's and young people's families (Haikkola 2011), knowledge on how these young people understand their transnational family lives and what this means for identity development is still a relatively under-researched area within the inter-disciplinary scholarship of migration studies, family studies, childhood and youth studies.

With regards to migrant children, when they are examined in the literature, there is a tendency to emphasise their neediness and difference (White et al. 2011) and so consequently the focus is on children from particular vulnerable categories such as refugee, trafficked or separated children (Gardener 2012). In contrast, the experiences of migrant children who fall outside of these categories - for example, having no language difficulties, living with their immediate family and enjoying longterm residence rights - remain largely unexplored. Similarly, in terms of migrant youths, the focus of much research scholarship generally seems converge around three key areas. The first, is concerned with migrant youth 'integration' into the nation and their social mobility within different countries (e.g. Crul and Vermulen 2003). In the UK this goes hand in hand with policy concerns over the supposed crisis of minority ethnic youths, specifically their perceived marginalisation and social exclusion from wider society. Over the past 20 years in the UK such concerns have been amplified by events such as the rioting between Whites and Asians in Northern English former industrial towns; the 7/7 bombings in London; violence and riots 
triggered by police shooting of the Black youth, Mark Duggan, and the broader issue of disenfranchisement of BME youth. More recently public and media focus has shifted on the sense of loyalty and identity of young British Muslims traveling abroad to join movements such as ISIS, the radicalization of Muslim children and young people and the problem of 'home grown' terrorists. A common feature of these debates attempting to understand these specific moments is their explicit or implied assertion that they are the result of the 'wrong' type of bonding social capital (Putnam 2001) within families and communities, with young people's continued links to a spiritual or physical homeland discouraging full integration and participation into societal norms and values. Within the contemporary political and common sense discourse, migrant youths' from certain ethnic, religious or racial groups such as South Asians, Africans, Caribbean and British-born Muslims more generally have become strongly associated with crime and criminal disorder, extremism and religious intolerance. Such attention overlooks other important dimensions of young people's lives and identities. Peggy Levitt's (2009) study suggests, for instance, that transnational ties and networks offer young people sources of potential empowerment particularly through their engagement in practices that transcend national borders. The young people she studies had skills and social contacts in both the countries where they lived and where their families came from. They could master several cultural repertoires, which they could use to respond to challenges and opportunities arising in their life. By growing up in transnational families where people, goods and ideas circulated between different countries, these young people acquired membership and knowledge of their homeland community which she saw as a potential source of power, information and support that could become mobilised at different points over their life-course.

The second body of scholarship prevalent in this area is preoccupied with the transnational trends of the children of migrants and the extent to which migrants' offspring engage in concrete transnational practices. (Portes 1999). Within this context the primary focus of debates is in understanding the factors that foster or hinder such transnational ties. The study of Louie (2006) on Chinese and Dominicans 'second generation' youth in the USA, for example, highlights the importance of factors such as the quality of parent-child relationships, the 
maintenance of ethnic language and the frequency of contact with the parents' country of origin in determining the degree of transnational identification for these young people. For Menjivar (2010), state policies and social class emerge as crucial factors in shaping transnational lives. The former influence the possibilities of people to travel across borders and thus maintain and renew their long-distance connections, the latter not only shapes the resources available to different families but also the ways in which transnational links are seen. In her study on Guatemalanorigin children living the United States, middle class children were those more inclined to see transnational connections in a positive light (a point also highlighted by Levitt 2009).

A third emerging body of research is focusing on the transnational experiences of youth who grew up separated from their parents or circulating for long stretches of time between two or more countries (see Mazzucato et al. 2011). The emphasis here is on the care arrangements set up by transnational parents and on the consequences of such arrangements for the well being of children. Particular attention has been paid to the consequences of the separations between parents and children especially in economic and psychological terms (Dreby 2007, Parrenas 2005, Schmalzbauer 2008, Muzzucato 2011)). These studies point out that children might benefit economically from such arrangements while suffering emotionally. Gender plays a role here, as children seem to find it harder to cope with separations in mother-away rather than father away families. They also critique studies on transnational children and caregiving practices for looking at the issue from the perspective and voices of adults. Recent studies drawing on the new sociology of childhood have started to take children's and young adults' agency seriously and to explore their subjective experiences of belonging and transnationalism (Ni Laoire et al 2011). Coe (2012), for instance, has explored how children in Ghana imagine transnational migration and how they are (or not) socialised into a culture of migration whereas Ni Laoire et al. (2011), looking at the experiences of a diverse group of children migrating to Ireland, have concluded that children's and youth lives can be embedded in local places as well as in global/transnational ones (see also Moskal 2015). 
In our analysis, we start from the premise of acknowledging that there are variations in children and youth's transnational experiences - for instance, some are born in homeland and migrated as young children, whilst others were born in host country to immigrant parents, while others are left behind or sent back for extended periods by their migrant parents. Despite those differences, however, we maintain that all of these groups, including those born or raised in the host country, have a link to their parents' homeland that is more than just symbolic. It is real and embodied in the sense that these individuals maintain communication across national borders, they express emotional as well as material attachments and allegiances to their parents' (or grandparents') homeland. This is expressed through everyday interactions with others in their daily lives.

Influenced by the work of Levitt (2009), we see transnational children and youths as embedded within a social field created by cross-border connections between sending and receiving society, irrespective of the frequency of physical travel to their country of origin. A transnational identity is formed by these children and young people through a series of material and symbolic flows across the borders of different countries. Migrant children and young people are engaged in frequent Skype/Facetime calls; phone calls, email correspondence and annual visits to their homeland, and this transnational communication activates the transnational social field and shapes their identification processes (anonymised for review). As with other scholars (Goulbourne et al. 2010 and Wessendorf 2010), we also recognise that transnational family relationships are a valuable social resource in re-affirming notions of cultural, ethnic and family belonging. These children and youths with strong transnational connections are 'doing family' oftentimes involving them transcending the boundaries of the nation-state, and crossing cultural divides and spatial distances express. Emerging out of this is a transnational family habitus that manifests itself in an embodied and physical way.

\section{Transnational family habitus framing ideas about families beyond borders}

Structural location and the ability to access and mobilise resources shape everyday 'family practices' (Morgan 2011) and results in 'family habitus': a structured set of 
values, ways of thinking and 'ways of being' that is built up over time within the family, through socialization and traditions (Archer et al 2012). This article develops the concept of 'transnational family habitus' to make sense of the experiences of children and young people of migrant origin who are embedded in transnational fields. Attempting to apply a Bourdieusian lens to the study of transnational migrants is in itself not new. For instance, Vertovec (2009:67) highlighted a 'bifocal habitus' and 'transnational habitus' as a particular dual frame of reference through which migrants constantly compare their situation in the 'home' country with that of the 'host one'. Kelly and Louis (2006) use the concept of 'transnational habitus' to show how Filipinos in Canada assign value and exchange and accumulate economic, social and cultural forms of capital across borders. Erel's work (2010: 644), exploring cultural capital, builds on these ideas about converting capitals and focuses on how Turkish and Kurdish migrant women in Britain and Germany adapt and apply meanings, knowledge, customs, achievements and outlooks which they bring to the new environment. Her argument is that migrants create new forms of capital and validation in migration. For Kelly and Louis (2006 habitus is a social/collective as well as personal phenomenon. However, the social (as well as spatial) boundaries of habitus formation is somewhat unclear in the work of Bourdieu. In their work they heuristically explore transnational habitus at the level of the ethnic group (as in Canadian-Filipino transnational habitus).

In contrast, through our analysis we explore transnational habitus at the level of family group formation by focusing understanding on how a particular (transnational) habitus is passed on to subsequent generations of family members. Taking the family as our unit of analysis allows us not only to move beyond methodological ethnicity (quote) but also to see similarities between our different groups. In particular, our concept draws attention to the collective everyday practices, including mundane and unconscious activities, that occur within families, thus extending the analysis beyond the active speculations in cultural capital that individual migrant parents conduct across borders which have started to be explored in the literature (Erel 2010, Weenick 2008). Attention to a transnational family habitus allows us to explore what it means for children and young people to grow up in a migrant family with transnational connections. 
Our use of the term 'transnational family habitus' gives attention to the types and levels of youth participation in family relationships that are transnational in nature and to the ways in which families (and their resources, values, sense of identity/self) inform children and young people's practices, notions of identity and opportunities within and beyond national boundaries. In doing so, we move beyond homogenising accounts of transnational families that depict all migrants as transcending geographical boundaries in their everyday life. Through our use of 'transnational family habitus' we elucidate how the maintenance of transnational connections rests upon relations of privilege, emerging out of the interaction between capital, habitus and field.

One way in which their transnational connections shaped their habitus relates to their ideas of what and who constituted families. In their accounts families emerged as broad, deterritorialised units where presence/absence, spatial proximity/distances, was normalised. They also expressed a clear sense of belonging to these units irrespective of the intensity or frequency of contact that they had with other members. For Keisha, as for many of our interviewees, having close family members in other countries and maintaining close relationships but oftentimes infrequent contact with them across borders, is assigned an important social value because it enables them be part of a globally dispersed network of family members. Members are able to individually and collectively define a family identity that is constituted by geographical, generational or cultural borders but rather is defined by their ability to maintain close familial connections that transcend these border. In Keisha's case the ability to invoke 'the family' on the basis of frequent physical absence but a shared history and heritage represents a normative unquestioned and taken for granted 'way of being' with regards to 'doing family' and related to this, understanding her own sense of self. In particular her transnational family habitus enabled Keisha to construct a Caribbean diasporic identity, unrelated to country of residence and citizenship. She utilised these kinship connections and practices as a resource in claiming allegiance and belonging to her kins' country of origin This is suggested by the following quotation: 
I would say my family is important to me [...]. We live in different parts of the world and we don't see each other often. But to me that's not important because we all identify with each other because of our history. My family makes me the person I am today and my identity comes through that family history and cultural heritage. We don't need to see each other everyday but knowing that they're out there supporting me help me to understand who I am. When we do meet up you wouldn't think that it's been ages since we last got together because we just pick up where we left off.

(Keisha, 23, Caribbean origin)

Our respondents showed familiarity with presence-absence and had direct experience of conducting close family relationships across distances. Bob, for instance, has experienced his relationship with his dad through long-distance separation which involved regular visiting in both directions and daily on-line communication. As the quote below suggests geographical mobility is embedded in his everyday family life.

OK, so I'm 14 years old, I live with my twin Hugo, whose also 14 years old because he's my twin and my mom. My dad is normally in Italy, because he works there, cause we also have a house there, where we go in the holidays, but he comes here every few weeks for weekend, it's been like that for quite a while now. He used to work here as well for a year, I think, or so, and before that we all lived together in Italy and even before that we all lived together in Germany, I'm not sure for how long. I think our dad is coming here, he has a job here, he got a job here so that means yeah! We'll be together again, reunited.

(Bob, 14, Italian-German origin)

Many of the young people noted that absent family members were just as important as physically present one. Absent members are made present in a variety of ways, 
e.g. through video and phone calls (Medianou and Miller 2012), but also through material objects that often occupy central places in migrants' homes (Anzola, forthcoming) and through family narratives and memory. These 'absent' members are usually talked about by the parents and a link is established between them and the young people. In addition to family narratives involving 'absent' family members, rituals acted as crucial way of affirming a collective transnational family identity.

Our participants demonstrated a sense of belonging to their transnational families through their commitment and participation in such rituals. We have written at length about this in some of our earlier publications on transnational families (anonymised for review). To summarise here, however, in our research it is clear that family rituals involve children and youths' participation in structured activities such as, for example, to celebrate life-cycle rituals such as baptisms, confirmations, weddings and family reunions. Sometimes they physically visited family members geographically dispersed across the globe to participate in such events but increasingly the use of virtual technologies meant that they were also able to be 'remotely present' and participate in family gatherings through remote means eg SKYPE/Facetime. It is also important to note other family rituals they were involved in that are mundane everyday activities such as travelling to airport in order to meet or say goodbye to family members but nevertheless represent an dimension of them 'doing families'. During the theatre sessions we did some physical theatre work with the young adults whereby they were asked to recreate physical images and dramatic scenes of them at the airport waiting to meet to family members or travelling to meet family members. It was interesting to observe how the airport represented a symbol of absence-presence and importance of movements backwards and forewards featured as an important aspect of the young people's lives - either as the travelling member or waiting to collect/drop off family members travelling to/from other destinations - reinforcing transnational relationships. However, the very rountine, unremarkable and very mundane aspects of this activity meant that is was not mentioned during interviews. It was only when we asked the young people to construct physical scenes and physical movement around 'their own family' versus 'the family' that this issue came to light. During the following reflection of one such 'airport' scene, one participant notes 
Coming home [to Norway] from [UK] it's the exact same routine. It's a bit cheesy but I love it secretly and its part of looking forward to going home. We have the same routine. My brothers, mum and dad always come to meet me [at airport], they always stand and wait for me in exact the same spot [at airport], and we sort of do this silly wave [mimics wave], which only our family get and is unique to our family

(Inga, 21, Norwegian origin)

The young people regarded Family visiting as an important aspect of a transnational family habitus. For Italian young people, especially, it is the main way of 'doing family' and keeping strong family ties and the young people derive a positive social value and strong sense of identity from doing these visits Due to the geographical proximity between Italy and UK, Italian young participants noted that they often visited family members in Italy at least three times a year, sometimes more, and have done so throughout their life. They are often spending their entire summer vacations sometimes with their parents and, when they worked, under the care of their grandparents in Italy. The young people saw these family visitsas part of multidirectional and intergenerational caregiving. In addition to the family visits to Italy, the the children and young people were directly involved in other types of care-activities including telephoning or skyping family relatives in Italy, exchanging small gifts with family members, hosting younger kin-members in the UK when they visited from Italy and also attending regular family celebrations with kin in Italy such as birthdays, Christenings etc meals. They generally viewed this type of care-giving as positive, taken for granted and important aspect of their transnational family habitus. Strong family values centred on the maintenance of emotional ties across the generations were fostered during these visits. Interestingly, the issue of free movement within the EU is now under threat as a result of Brexit vote in the UK potentially challenging these practices.

The above evidence suggests that young people's everyday actions; regular activities and everyday life are shaped by a 'transnational family habitus' i.e. by 
values, practices, cultural discourses and identifications as well as resources that transcend national boundaries. In the next section we explore the impact of such habitus on their lives.

\section{Transnational family habitus and its impact on capitals}

Our analysis indicates that those individuals with a transnational family habitus are able to better circulate cultural capital resources within their networks in order to further increase the social assets and social capital of group members. In the Italian studies, for instance, language represented a key marker of transnational family habitus. Multilingualism was regarded as an important asset by both Italian parents and children offering the potential for inter-cultural communications and skills.

Participant: Well, being multilingual, I find that amazing, if you can speak different languages that you know a whole different way of communicating with another human being and I find it a bit saddening that some people only know one way and what happens if that one way fails? And also that one way some people don't know that way of communication so you need other ones

Interviewer: so you feel that for you is a good to having these multiple languages?

Participant: it is a good thing and sometimes overlooked a bit cause when you think about it's just.... because with a language, once you know a whole new language, say with the 3 languages I can speak, I can think of three times as many things to put things in so if I can't say something in one language plenty more languages, well 2 more languages that I can put things, try to choose from, see what's working. Also, it kind of ....changes the thought process because you can think in whichever language suits your needs best.

(Hugo, 14, Italian-German origin) 
Language competence was not only perceived as an asset for cross-cultural communication and a potential advantage, it also served the purpose of strengthening a sense of belonging within families. Families, for instance, developed their own language practices, which sometimes meant mixing languages or words.

Participant: mhm I speak English most frequently and obviously well I'm best at English since I go to school there, I learn all of the grammar English, I have English classes, math classes, all the vocabulary comes from English, but speak German with my brother and my mom and Italian with my dad, so I'm more often more regularly speak German than Italian but once we get go to Italy after a few days the Italian returns and flowing out maybe, yeah and the same for Germany.

(Bob, 14, Italian-German origin)

Knowing a different language, any language, is potentially advantageous as Bob highlights:

Also if you understand, even if they are not connected, if you understand one language you can understand another language quite a lot better because you can translate a phrase or a world in that other language, not only into feelings or something, but you can translate it into words you can understand better, yeah.

(Bob, 14, Italian-German origin)

This particular aspect of family habitus has the potential to generate social mobility for the migrant origin's youths. However, this applies to those being able to speak fluently in high-prestige European languages (Italian, as well as French, German, and Spanish) who can regard this ability to do so as a cultural asset, facilitating their ability to move freely within/across class-based boundaries. It is important to recognise, however, that knowing a second language and the potential advantages 
this bring operates within a racialized context and within the context of White privilege. Bilingualism in other languages can be less rewarding and language can be used to draw a 'bright' ethnic boundary (Alba, 2005) between the majority and migrant populations. The young people of African and South Asian descent, who spoke second languages, recognised that speaking a second language was not valued and disadvantaged them by reinforcing their status as 'Other'. Nonetheless, a 'transnational family habitus' allowed Black (African and Caribbean) youths who in policy terms are conventionally marked out as 'other', to strategically respond to their position as 'outsiders' 'ethnic other' in the UK, by acquiring social and cultural capital resources through which to affirm and validate their cultural belonging. During interviews it was observed how common cultural signifiers such as food, sports (such as athletics via the key figure of Usain Bolt and the Jamaican flag as a commericalised product on Puma sports brand) represented broader makers of Black youth identity, itself heavily influenced by these young people's diasporic and transnational connections to their African and Caribbean heritage. They were able to use this understanding of cultural identity as an asset, during a policy era of advancing neo-liberal markets, through the development of small and medium enterprises as a way of easing economic recession. The example of Victor provides one such example. Victor, a black youth of Angolan descent and familial links to Portugal decided to develop an ethnic specific social enterprise initiatives across neighbouring geographical London boroughs where large number of BME communities reside. He explains:

It was one of those 'Dragon's Den' [tv programme] kinds of things where you basically pitch a project and during the Olympics they [London 2012] wanted something to create a legacy, so I had an idea and I applied. it had like a panel members that were all judging who was the best kind of concept and whatnot and Young Stars won. Basically my project Young Stars is a concept, it's like a movement, a culture, it's about Black youth empowerment and basically bringing up or helping young people, trying to find themselves through youth empowerment, focusing on the positive Black youth out there instead of the negative 1 or $2 \%$. My plan is to take the business model 
globally, developing franchises in Lisbon and Brazil, where I have the family connections

(Victor, 20, Angolan-Portuguese origin)

In Victor's case his motivation to set up his business model were a direct result of two factors. Firstly, Victor's extended family across the generations have been businesspeople and professionals traders. In Victor words he has 'business is in blood' and explains 'my great great grandfather was a market trader who couldn't read or write but he made sure his children could; my great and grandparents were market traders too, now my mum uncles and aunts all University educated, they went to University in Lisbon, Toronto, Sao Paola, Brazil but all have successful businesses and I've got many cousins doing the same thing and they live all over the world. What they tells me is if you want to succeed in life its important to have your on business, that way your are in charge of yor own destiny'. Victor utilised family connections to his golobally dispersed family members and regular family visits to Angola and also Portugal, to learn from and draw on and the skills, values knowledge, networks and financial capital of these family members. Victor's transnational family habitus has provide his with the ability to transcend and traverse the geographical borders in order to access resources and capital, emerging from his transnational family networks, across geographical borders and establish an entrepreneurial opportunity in the UK. Of course it is important to acknowledge that the use of these ethnic markers for commericalisation purposes does not always result in ethnic minority youth accumulating capital. Trietler (2013) makes this very point arguing that the appropriation of Black cultural resources, feeds into neo-liberal economic projects without in many cases empowering Black youths who develop these cultural forms.

Secondly, Victor's decision to set up a business enterprise is also influenced by what his perceived to be the limited professional employment opportunities available to him as a result of being Black and male in Britain. Indeed the value of having a transnational family habitus for Victor, as with other Black youths, must be understood within the wider context of social exclusion (EHRC, 2010). The collective relationships provided by these transnational kin-based connections, unconstrained 
by national boundaries, provided Victor with a sense of security and belonging against feelings of racial discrimination and social exclusion experienced as part of their daily lives experience (see also Reynolds 2006a/b, 2010, Zontini 2010; Goulbourne et al. 2010). In these austere times unemployment is on the rise generally across all ethnic groups. Nonetheless this problem has been more acute for Black and other minority youths (BME) with a recorded high of them not in any form of employment, education or training (also known as NEETs) (Department of Education 2011, IPPR 2010). Statistics show nearly $50 \%$ of black people aged 16 to 24 are unemployed. Such is the scale of the problem in particularly socioeconomically disadvantaged neighbourhoods that those with social capital and active links to the homeland are returning 'home' to the Caribbean (Reynolds 2011b), as well as other countries of origin leaving behind family members in the UK.It is important to stress, however, that a transnational family habitus was central to this process. The opportunity to 'return', set up business or even study in countries where kinship connections exist operates in the context whereby young people understand and value their ways of 'doing family' across geographical boundaries as a normative family practices.

\section{Limitations of Transnational family habitus}

Having a transnational habitus might create several opportunities but with these can come challenges. In the study with Italian second generation children, the transition between the different, multiple and complex worlds they inhabit as a result of having a transnational identity was often commented on by them. These children have to learn to inhabit different words that involve knowing how to transition effortlessly between them. These can be the worlds of Italy vs. the UK but also the world of school vs. the world of home. They develop different ways of being in different places and each place might provide different needs. Hugo talks about moving from Italy to England after the holidays:

Participant: it's kind of like I thigh ten up again when I come into England and when I go to Italy I loosen up a bit, kind of .... 
interviewer: why do you think that is the case?

participant: because I feel more relaxed there because of the weather and because no school and holidays and also I get to see my dad and that's nice and ... also... this is difficult, mmhh l'd say mainly I just let go of my worries, it's half to do with the holidays and half to do with actually Italy but also the Italians kind of make you feel more at home than the British people kind of ish (Hugo, 14, Italian origin)

Hugo's middle class status affords him the advantage of having two houses - which consolidates his feeling of having two 'homes'. Some of the other Italian participants were also similarly aware of their privileged (class and racialized) position. Here is Hugo again responding to the question about how he thought the media talk about people who come from abroad in the UK.

Participant: mmhh depends from where they are because if they are from some war torn country they are not seen as very.... not seen vey nicely, which is a bit stupid, because you'd think that there be some sympathy for someone who's just escaped with their life from a country whose been bombed and which has a civil war going on or something but that's yeah, for people like, who are just moving from a European country or something they are just kind of absorbed, I guess, engulfed into the Englishness and they just say like "oh hi what's up? You can be English now! (With a mocking voice)" They don't really notice too much, I guess.

(Hugo, 14, Italian origin)

Working class migrants are much less likely to have a transnational family habitus because they face greater constraints in keeping these important transnational practices going. This is clear from our interviews with Italian working class post-war migrants who recounted their travelling practices over the years. As Maria explains, they had to endure long periods of no visiting as their economic conditions and their working schedules did not allow them to move. 
Yeah, you not do anything else, no holiday, only to the village to see the family cos you had that to do (...) [I went] the first time [after] 8 years and then after 4 years and then after 2 years and then, after the girls was married, every year. My mamma was there and I think: 'well after next year she might not be there and err... we went every year'.

In contrast, however, middle class youth are more likely to have a transnational family habitus because they possess more financial resources to travel and also jobs that allow them more flexible schedules that enable them to travel more frequently. Their better education also means that they have access to new technologies that allow them to stay in contact with families and friends back home.

These examples show that, although a transnational family habitus is not the prerogative of the better off, it is shaped by access to broader social and economic resources affecting the lived experiences of transnational families. Transnational family habitus also reveals important issues about gender divisions, gendered power dynamics and gendered processes of inclusion and exclusion in transnational family relationships. In spite of the current rhetoric of family democratisation, the issue of the gendered division of labour was a source of tensions and conflict within the young people we interviewed, with girls and young women still being expected to share burden of 'doing family' transnational, including the maintenance of family connections, and related care-giving activities previously mentioned.

Gender, however, is also tied with generation as older women may have more power and control than younger ones, while boys on the whole have more freedom and autonomy from the family than girls do. Foner (2007) highlighted how intergenerational relations are a key aspect of transnational family life, with much attention in the migration studies literature placed on intergenerational conflict. These relations, however, are not fixed and static as they are both about change and permanence. Our research uncovered different types of intergenerational tensions 
but also ways in which connections developed across the generations that often meant transnationally.

In our studies, some Italian young women felt that their families 'protection and support' was often a double-edge sward as those giving support wanted to influence the choices of those receiving it and that support was linked to obligations and adherence to shared norms and values. Some of our interviewees discovered through their experiences that departing from such expectations would result in a decline in support. These strong and often tense relationships of dependence, especially between mothers and daughters, occurred both locally and transnationally (Goulbourne et al. 2010, Zontini 2010).

\section{Conclusion}

In this article we develop the concept of transnational family habitus to understand the reasons why transnational networks persist across the generations. Through the use of this concept we have shown that migrant children and young people of migrant origin 'do families' beyond the borders of the nation state and the implications this has on their life and opportunities. Such transnational family habitus is seen here as an asset which can potentially disrupt conventional understandings of belonging and processes of inclusion and exclusion. However, we also have detailed how social divisions of class, race, and increasingly migration status, shape such habitus. This enables us to expand debates on youth of migrant origin beyond a focus on the impact on separation from parents, the extent of their transnational engagement and the impact of the latter on their integration in receiving societies.

Our research looks at migrant children and young people as members of wider family networks that go beyond the nuclear ones privileged by much family research and thus expand our understanding of transnational youth experiences beyond the prevailing focus on the effects of parent-child separations (Mazzucato et al. 2011). The real and symbolic transnational engagements are pervasive taken from granted 
aspects of family life. They might vary in intensity from family to family and from time to time but stay latent and can be activated or re-activated at different times.. Rather than measuring the frequency of such engagements we believe that a more fruitful approach centres on exploring how young people frame their collective relationships in ways that may or may not transcend national borders and the effects that a transnational family habitus might have on their experiences. Contrary to popular perceptions, having a transnational family habitus and being integrated in the receiving societies is not a zero-sum game. What we offer in this article is a framework that seeks to de-pathologies this family experience, seeing it as a potential asset, while at the same time highlighting the stratifying consequences such experience might have for different groups of youth.

\section{References}

Alba, R. (2005) 'Bright vs. blurred boundaries: Second-generation assimilation and exclusion in France, Germany, and the United States', Ethnic and racial studies, $28(1), 20-49$

Anderson, B. (2006) Imagined communities (New ed.), New York \& London: Verso Anthias, F. (2007) 'Ethnic ties: Social capital and the question of mobilisability', The Sociological Review, 55(4), 788-805

Anzola. J. (forthcoming) Stories and 'Things' That Matter: Exploring Culturally

Diverse Same-Sex Intimacies Through Narratives and Domestic Materiality, unpublished PhD thesis, University of Nottingham

Archer, L., DeWitt, J., Osborne, J., Dillon, J., Willis, B., and Wong, B. (2012) 'Science Aspirations, Capital, and Family Habitus: How Families Shape Children's Engagement and Identification With Science', American Educational Research Journal, 49 (5), 881-908

Baldassar, L. and Merla, L. (eds) (2013) Transnational Families, Migration and Kinwork: From Care Chains to Care Circulation, London: Routledge 
Bauer, E., and Thompson, P. R. (2006) Jamaican hands across the Atlantic, Ian Randle Publishers

Boal, A. (1979) Theatre of the Oppressed, New York: Theatre Communications Group

Bonizzoni, P. and Boccagni, P. (2013) 'Care (and) circulation revisited: a conceptual map of diversity in transnational parenting', in L. Baldassar and L. Merla (eds.)

Transnational families, migration and kin-work: From care chains to care circulation, London: Routledge

Bornat, J. (2005) 'Recycling the evidence: Different approaches to the reanalysis of gerontological data', Forum Qualitative Sozialforschung/Forum: Qualitative Social Research, 6(1)

Bourdieu, P. (1986). 'The Forms of Capital', in J. G. Richardson (eds.) Handbook of Theory and Research in the Sociology of Education, Westport, CT: Greenwood Press, 241-258

Bryceson, D. and Vuorela, U. (eds.) (2002) The Transnational Family: New European Frontiers and Global networks, Oxford: Berg

Charsley, K., and Shaw, A. (2006) 'South Asian transnational marriages in comparative perspective', Global Networks, 6(4), 331-344

Christou, A. and King, R. (2010), "Imagining 'home': diasporic landscapes of the Greek second generation", Geoforum, 41, 638-46

Coe (2012) "Growing Up and Going Abroad: How Ghanaian Children Imagine Transnational Migration", Journal of Ethnic and Migration Studies 38(6), 913-931

Crul, M., and Vermeulen, H. (2003) 'The second generation in Europe', International migration review, 37(4), 965-986

Department for Education (2010) Participation in Education, Training and Employment: 2010 https://www.gov.uk/government/statistics/participation-ineducation-training-and-employment-by-16-to-18-year-olds-in-england--2 
Dreby, J. (2007) 'Children and power in Mexican transnational families', Journal of Marriage and Family, 69(4), 1050-1064

Equality and Human Rights Commission (2010) How Fair is Britain? Report, London: Erel, U. (2010) 'Migrating cultural capital: Bourdieu in migration studies' Sociology, 44(4), 642-660

Gardner, K. (2012) 'Transnational migration and the study of children: An introduction' Journal of Ethnic and Migration Studies, 38(6), 889-912

Glick Schiller, N., Basch, L., and Blanc-Szanton, C. (1992) 'Transnationalism: A new analytic framework for understanding migration', Annals of the New York academy of sciences, 645(1), 1-24

Goulbourne, H., and Solomos, J. (2003), 'Families, ethnicity and social capital', Social Policy and Society, 2(04), 329-338

Goulbourne, H., Reynolds, T., Solomos, J. and Zontini, E. (2010) Transnational Families, Ethnicities, Identities and Social Capital, London: Routledge

Haikkola, L. (2011) 'Making connections: Second-generation children and the transnational field of relations', Journal of Ethnic and Migration Studies, 37(8), 12011217

Henderson, S., Holland, J. and Thomson, R. (2006). 'Making the long view:

Perspectives on context from a qualitative longitudinal (QL) study', Methodological Innovations Online, 1(2),

http://erdt.plymouth.ac.uk/mionline/public html/viewarticle.php?id=29\&layout=html

IPPR (2010) Youth Unemployment and the Recession, London IPPR

Kasinitz, P., Waters, M. C., Mollenkopf, J. H., and Anil, M. (2002) 'Transnationalism and the children of immigrants in contemporary New York', in Levitt, P. and Waters, M. The Changing Face of Home: The Transnational Lives of the Second Generation, Russell Sage Foundation, 96-122 
Kilkey, M. and Merla, L. (2013) Transnational Families' Care-Giving Arrangements: towards a Situated Transnationalism, Global networks, 14(2), 210-229

Kofman, E., Kraler, A., Kohli, M. and Schmoll, C. (2011) 'Issues and debates on family-related migration and the migrant family: a European perspective', in A. Kraler, E. Kofman, M. Kohli and C. Schmoll (eds) Gender, Generations and the Family in International Migration, Amsterdam: Amsterdam University Press Levitt, P. (2001) The Transnational Villagers, Berkeley: University of California Press Levitt, P. (2009) 'Roots and routes: Understanding the lives of the second generation transnationally' Journal of Ethnic and Migration Studies, 35(7), 1225-1242

Louie, V. (2006) 'Growing up ethnic in transnational worlds: Identities among second-generation Chinese and Dominicans', Identities: Global Studies in Culture and Power, 13(3), 363-394

Madziva, R. and Zontini, E. (2012) 'Transnational mothering and forced migration: understanding the experiences of Zimbabwean mothers in the UK', The European Journal of Women' Studies 19(4), 428-43

Mand, K. (2010) "I've got two houses. One in Bangladesh and one in London... everybody has': Home, locality and belonging (s)", Childhood, 17(2), 273-287

Mauthner, N. S., Parry, O. and Backett-Milburn, K. (1998) 'The data are out there, or are they? Implications for archiving and revisiting qualitative data', Sociology, 32(4), 733-745

Mazzucato, V. and Schans, D. (2011) 'Transnational families and the well-being of children: Conceptual and methodological Challenges, Journal of Marriage and Family, 73(4), 704-712

Madianou, M. and D. Miller (2012) Migration and New Media, London: Routledge. Menjívar, C. (2002). "Living in two worlds?: Guatemalan-origin children in the United States and emerging transnationalism", Journal of Ethnic and Migration Studies, 28 (3), 531-552.

Morgan, D. (1996) Family Connections, Cambridge: Polity Press 
Morgan, D. (2011) Rethinking Family Practices, Basingstoke: Palgrave Macmillan

Moskal, M. (2014) 'Polish migrant youth in Scottish schools: conflicted identity and family capital', Journal of Youth Studies, 17(2), 279-291

Moskal, M. (2015) 'When I think home I think family here and there': Translocal and social ideas of home in narratives of migrant children and young people Geoforum, $58,143-152$.

Parreñas, R.S. (2005) Children of Global Migration: Transnational Families and Gendered Woes, Stanford, CA: Stanford University Press

Portes, A. (2001) 'Introduction: the debates and significance of immigrant transnationalism' Global networks, 1(3), 181-194

Portes, A. and Rumbaut, R.G. (2001) Legacies: The Story of the Immigrant Second Generation, Russell Sage Foundations

Potter, R. B., Conway, D., and Phillips, J. (2005) The Experience of Return Migration: Caribbean Perspectives, Gower Publishing, Ltd.

Purkayastha, B. (2005) Negotiating Ethnicity: Second Generation South Asians Americans Traverse a Transnational World, New Brunswick, NJ: Rutgers University Press

Putnam, R. D. (2001) Bowling Alone: The Collapse and Revival of American Community, Simon and Schuster.

Reynolds, T. (2010) 'Transnational family networks, cultural belonging and social capital among second-generation British-Caribbean 'returning' migrants' Ethnic and Racial Studies 33(5), 797-815

Reynolds, T. (2006a) 'Caribbean young people, family relationships and social capital', Journal of Ethnic and Racial Studies 29(6), 1087-103

Reynolds, T. (2006b) 'Bonding social capital within the Caribbean family and community', Journal of Community, Work and Family, 9(3) 273-90

Reynolds, T. (2011) 'Caribbean second generation return migration: identities, 
transnational family relationships and 'left behind' kin in Britain', Mobilities 6(3), 53552

Ryan, L., Sales, R., Tilki, M., and Siara, B. (2008) 'Social networks, social support and social capital: The experiences of recent Polish migrants in London', Sociology, 42(4), 672-690

Schmalzbauer, L. (2008) 'Family divided: The class formation of Honduran transnational families', Global Networks, 8(3), 329-346.

Sime, D., and Fox, R. (2015) ‘Home abroad: Eastern European children's family and peer relationships after migration', Childhood, 22(3), 377-393

Thomson, R. and Holland, J. (2003) 'Hindsight, foresight and insight: the challenges of longitudinal qualitative research', International Journal of Social Research Methodology, 6(3), 233-244

Treitler, V.B Vilna Bashi (2013) The Ethnic Project: Transforming Racial Fiction into Ethnic Factions, Stanford University Press.

Vertovec, S. (2009) Transnationalism, London: Routledge

Weenink, D. (2008) 'Cosmopolitanism as a form of capital parents preparing their children for a globalizing world', Sociology, 42(6), 1089-1106

Wessendorf, S. (2010) 'Local attachments and transnational everyday lives: secondgeneration Italians in Switzerland', Global Networks, 10(3), 365-382

White, A., Ní Laoire, C., Tyrrell, N., ad Carpena-Mendez, F. (2011) 'Children's roles in transnational migration', Journal of Ethnic and Migration Studies, 37(8), 1159-1170

Zontini, E. (2010) 'Enabling and Constraining Aspects of Social Capital in Migrant Families: Ethnicity, Gender and Generation', Ethnic and Racial Studies 33(5), 816831 
i Migrant mothers caring for the future: creative interventions in making new citizens, http://www.open.ac.uk/socialsciences/migrant-mothers/index.php

ii Participatory Action Research (PAR): Participatory Theatre and Walking Methods' Potential for Co-producing knowledge, funded by ESRC and National Centre for Research Methods (2016-

2018) http://www.ncrm.ac.uk/research/PASAR/ 